\title{
Heritage assets in financial reporting: a critical analysis of the IPSASB's consultation paper
}

\author{
Lucia Biondi, Fabio Giulio Grandis and Giorgia Mattei \\ Department of Business Studies, Roma Tre University, Roma, Italy
}

\begin{abstract}
Purpose - Within the stream of research on public sector accounting standards, heritage asset accounting represents a difficult and challenging issue. This paper intends to join the debate on heritage reporting by carrying out a critical review of the Consultation Paper (CP) "Financial Reporting for Heritage in the Public Sector" issued by the International Public Sector Accounting Standards Board (IPSASB) in order to highlight its strengths and weaknesses and to make recommendations.

Design/methodology/approach - To this end, the current study adopts document analysis as a qualitative research method by referring to Italy as a typical and critical case study. Moreover, the authors actively took part in the Italian working group on heritage assets reporting, so they are well-informed people about the Italian point of view as well as the broad discussion underpinning the Italian response.

Findings - Evidence demonstrates that, although the proposals included in the $\mathrm{CP}$ represent a new step towards an organic regulation of heritage asset reporting, if these preliminary views are confronted with the reality of an emblematic context, as in the Italian case, much room for improvement remains regarding the definition, recognition, measurement and disclosure of such assets.

Originality/value - The originality of the paper lies in its contribution to overcoming the current controversial aspects of heritage assets reporting and the issuing of an accounting standard. In doing so, the authors also attempt to answer the call made by Anessi-Pessina et al. (2019) to investigate in detail an individual country experience to better understand the state of the art in national and international accounting standards on heritage assets.
\end{abstract}

Keywords International Public Sector Accounting Standards (IPSAS), Accrual accounting, Recognition, Measurement, Disclosure, Italy

Paper type Research paper

\section{Background to the study}

The harmonization of accounting systems is currently undergoing an intense debate, concerning first the accounting systems of the private sector and, subsequently, of the public sector. Focusing on the latter, during the New Public Management (NPM) era (Hood, 1991, 1995), there has been a push to introduce accrual accounting systems (Christiaens and Rommel, 2008). As a consequence, some public sector entities started to adopt accruals accounting but based on different standards. To tackle this problem, the International Public Sector Accounting Standards Board (IPSASB) started to develop International Public Sector Accounting Standards (IPSASs), considering the specific requirements of the public sector (Anessi-Pessina et al., 2019). The need for accrual accounting information was also emphasised by the European Commission, via the European Directive n.85/2011 (EU Commission, 2013,

\footnotetext{
(C) Lucia Biondi, Fabio Giulio Grandis and Giorgia Mattei. Published by Emerald Publishing Limited, This article is published under the Creative Commons Attribution (CC BY 4.0) licence. Anyone may reproduce, distribute, translate and create derivative works of this article (for both commercial and noncommercial purposes), subject to full attribution to the original publication and authors. The full terms of this licence may be seen at http://creativecommons.org/licences/by/4.0/legalcode

The authors gratefully acknowledge the Studies and Research Division of the State General Accounting Department (RGS), Italian Ministry of Economy and Finance (MEF), for the opportunity to take part in the research project "Heritage in Financial Reporting".
}

Heritage assets in financial reporting

Received 9 September 2020 Revised 8 January 2021 9 March 2021

Accepted 13 March 2021 
JPBAFM 33,5

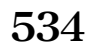

p. 2). The IPSASs are, so far, the only internationally recognized public sector accounting standards based on the accrual principle. However, the EU Commission, after having verified the adequacy of these standards in the European context, concluded that it would be better to create a specific set of standards, inspired by the IPSASs, which take into account the peculiarities of the EU Member States: European Public Sector Accounting Standards (EPSASs). Considering that the future new set of principles will also be based on accrual accounting, it is crucial to understand why this accounting system was chosen.

Over the years, scholars have identified benefits and opportunities for public sector entities to adopt accrual accounting (Carlin, 2005; Christensen, 2002; Guthrie, 1998; Lapsley et al., 2009; Manes Rossi et al., 2016; Paulsson, 2006, Evans, 1995; Wynne, 2007, Andriani et al., 2010; Anessi-Pessina and Steccolini, 2007); among these, for the purposes of this paper, the improvement management of assets is highlighted (Andriani et al., 2010; Anessi-Pessina and Steccolini, 2007). In the accrual accounting context, some scholars assert that the definition of an asset, based on private-sector meanings, creates distortions and, as such, is of limited use in decision-making in the public sector (e.g. Barton, 2005; Carnegie and Wolnizer, 1999, 2002; Carlin, 2005). Moreover, when one is faced with a particular and specific asset such as a "public cultural heritage" (e.g. museum collections, heritage collections in libraries, art gallery collections, general collections in libraries, historical documents and historical monuments (Schuler et al., 2015)), this becomes even more complex. First of all, it is therefore necessary to specify what is meant by "public cultural heritage". In this context, the present work attempts to provide a definition for public cultural heritage items and when they become assets, subsequently focusing on heritage asset reporting. Within this stream of research, heritage asset accounting represents a difficult and challenging issue (Adam et al., 2011; Biondi and Lapsley, 2014), with many concerns raised about: (1) a proper definition of such items; (2) the opportunities for recognizing them in financial reporting statements; (3) the measurement criteria to adopt and (4) the additional disclosures to provide.

Notwithstanding a prolific body of literature and several national standard setters' attempts to tackle these matters, no agreed-upon definition or accounting treatment has been reached to date. Not even the IPSAS 17 (Property, plant and equipment) or IPSAS 31 (Intangible assets) provide a definitive solution, leaving public sector entities the choice of which accounting approach to adopt. This has resulted in a variety of practices in different jurisdictions and, consequently, reduced comparability (Mattei et al., 2020). In 2017, the IPSASB initiated a discussion by releasing the Consultation Paper (CP) "Financial Reporting for Heritage in the Public Sector" (IPSASB, 2017a). The aim was to receive views from constituents in order to provide guidance on this topic and, ultimately, to meet the information needs of users of General Purpose Financial Reports (GPFRs) for accountability and decision-making purposes. Among the 40 comment letters gathered (for an overview, see IPSASB, 2017b; Aversano et al., 2020; De Wolf et al., 2020), Italy also expressed its position through the Italian Ministry of Economy and Finance (MEF). The reason underpinning the decision of the MEF to assume an active role in this process is that, although Italy is famous worldwide for its national heritage, no national accounting standard for such items exists (as we will explain in Section 3). The lack of a specific standard governing the cultural heritage reporting is the result of the absence, until a few years ago, of an accrual accounting system. In fact, Italy has always been characterized by the adoption of a legal accounting system approach (Dabbicco and Mattei, 2020). Even following the reform of the public sector accounting systems, which began in 2009 , nothing has substantially changed in this regard.

Against this backdrop, this paper intends to join the debate on heritage reporting by examining whether the $\mathrm{CP}$ represents a step forward towards the issuing of an accounting standard for heritage assets under the accrual basis of accounting, when looking at an emblematic national context, such as Italy. This study is the first step of a broader research project that involves the University of Roma Tre, the Italian MEF and the Italian Ministry of 
Cultural Heritage and Activities and Tourism (MiBACT). To meet our goal, we carried out a critical review of the $\mathrm{CP}$ in order to highlight its strengths and weaknesses and to make recommendations. Hence, we adopted document analysis as a qualitative research method by referring to Italy as a typical and critical case study. In fact, as better explained in the methodological section, on the one hand, the strong presence and huge variety of heritage assets make Italy a typical case study; on the other hand, since it entails generalization to other contexts, Italy is also a critical case (Patton, 1990; Yin, 2003).

The originality of the paper lies in its contribution to overcoming the current controversial aspects of heritage assets reporting and the issuing of an accounting standard. In doing so, we also attempt to answer the call made by Anessi-Pessina et al. (2019) to investigate in detail an individual country experience to better understand the state of the art in national and international accounting standards on heritage assets.

The remainder of the paper is structured as follows: Section 2 focuses on the debate around heritage asset accounting (both from academic and standard setters' viewpoints) and its unresolved issues, which lead to the research question; Section 3 describes the Italian state of the art; Section 4 explains the methodology we followed; Section 5 provides the critical review of the CP; Section 6 contains the discussion and, finally, Section 7 draws some conclusions, highlighting both theoretical and practical implications, as well as the limitation of the study.

\section{The debate around heritage assets: a never-ending story?}

\subsection{The academic viewpoints}

Heritage assets are a controversial subject. The discussion begins when thinking about what heritage assets are and what kind of items should be included. Far from finding an agreedupon definition (Adam et al., 2011), heritage items can be better identified by their characteristic features: the importance of preserving and maintaining them for the enjoyment of current and future generations; their multifaceted value (cultural, environmental, educational, historical, artistic, archaeological and social), which is difficult to present in monetary terms; their inalienability; their uniqueness; their undetermined life and their nonrival and non-excludable consumption attributes (Biondi and Lapsley, 2014).

The debate around heritage asset accounting is rooted in a not too recent past. To the best of our knowledge, it can be dated back to the 1970s, when some Italian scholars began to discuss the difficulties - but not the impossibility - of attaching a monetary value to cultural heritage (Buscema, 1976; Cassandro, 1970). Notably, these authors questioned the issue of inalienability. They believed that, even though these goods cannot be sold, and therefore one cannot identify their market value, this does not imply that they do not have a financial value or do not have any impact on the financial statement (Paoloni and Grandis, 2007).

However, a significant interest in this topic spread internationally in the 1980 s from the Anglo-Saxon countries (the USA, Australia and New Zealand), giving rise to a "tit for tat" between scholars and practitioners.

The main argument concerned the possibility of considering heritage items as "assets" from an accounting perspective and, consequently, recognizing them on the balance sheet. As we will discuss in more detail later, an asset is generally defined by international conceptual frameworks as a present resource controlled by an entity as a result of past events, from which economic benefits can arise (IASB, 2018; FASB, 2008). On this subject, two main opposing views exist: on the one hand, there are those who support the idea that heritage items are assets (Hone, 1997; McGregor, 1999; Micallef and Peirson, 1997; Rowles, 1992); and on the other hand, there are those who believe that they should instead be considered as something else. Furthermore, in this second case, they should be recognized separately from the financial statements (Carnegie and Wolnizer, 1995, 1996; Jaenicke and Glazer, 1991, 1992; Nasi et al, 2001; Stanton and Stanton, 1997). 
JPBAFM 33,5
For example, Mautz $(1981,1988)$ claimed that, since their maintenance and preservation require capital outflows, they should be treated as "liabilities" instead. Specifically, he introduced the concept of "facilities" to identify "properties essential to the purpose of a notfor-profit organization that are acquired to facilitate the transfer of resources outward" (Mautz, 1988, p. 125). Similarly, Pallot (1990) argued that such goods are "community assets", in that they embed a social purpose, belong to the citizens and cannot be sold. Barton (2000) adopted a trusteeship approach to explain the same concept: "The government holds them in trust for present and future generations and has a responsibility to protect and preserve them" (p. 231). Therefore, he believes that: "The correct method of accounting for assets managed on behalf of others is that they be treated as assets held in trust by the custodial entity" (Barton, 2005, p. 438). More recently, by mixing the two concepts proposed by Pallot (1990) and Barton (2000, 2005, 2009), Christiaens et al. (2012) suggested the term "community asset held in trust" to distinguish those governmental capital goods to which the law or the government has attributed a social status from those that are business-like capital goods, having an economic status.

Conversely, there are academics and standards setters who support the idea that heritage goods can be treated as assets from an accounting perspective. Micallef and Peirson (1997), for example, referred to cultural, heritage, scientific and community collections (CHSCCs), arguing that most of them fit the definition of an asset and therefore can, and indeed should, be recognized in the pursuit of a proper management of assets and to provide users with an indication of the use of resources by the entities that control them. Similarly Hone (1997, p. 42) concluded that valuing public collections is an essential component of a sound public management system, in that it allows one to assess and monitor: (1) the allocation of funds between competing uses; (2) the performance of public managers and (3) the application of scarce public resources in a socially and economically responsible way. These considerations can also be extended to all other heritage items. In some authors' opinion, heritage assets should not be considered as different from other asset categories, since traditionally recognized capital goods sometimes display similar characteristics (McGregor, 1999; Rowles, 1992). For instance, inalienability, the absence of an active market, and the indefinite useful life can also be found in other assets (e.g. infrastructure assets), without precluding their evaluation, regardless of the nature of the reporting entity.

More recently, other authors, while acknowledging the possibility of considering heritage items as assets, have warned of the danger that measuring the economic value of heritage assets may negatively affect the perception of their cultural value, asserting that it is necessary to consider how both could be reported (Ellwood and Greenwood, 2016).

\subsection{The standard setters' viewpoints}

Some standard setters share the same opinion about considering heritage items as assets. Australia and New Zealand were among the first countries addressing this question (Woon et al., 2019). The Australian Accounting Standards Board (AASB) indeed believes that heritage assets are a subset of property, plant, and equipment that should be subject to the same definition and accounting treatment (AASB 116 - AASB, 2015). The same is true in New Zealand (PBE IPSAS 17 - NZASB, 2014), even if the Treasury Accounting Policy Team in 2002 issued a specific Valuation Guidance for Cultural and Heritage Assets intending to "provide practical guidance on the valuation of heritage and cultural assets in the context of New Zealand general purpose financial reporting, so as to facilitate a consistent and cost effective approach across the public sector" (Treasury Accounting Policy Team, 2002, p. 3).

When considering heritage items as assets, thought should also be given to their accounting treatment regarding how they should they be recognized, how their value can be measured and whether they can be accounted for as traditional fixed assets or need a specific accounting standard. 
In this regard, the IPSASs do not appear to provide a definitive solution. In fact, both IPSAS 17 "Property, plant and equipment" (IPSASB, 2000) and IPSAS 31 "Intangible assets" (IPSASB, 2010) do not require tangible or intangible heritage asset recognition, leaving public sector entities with a choice of which accounting approach to adopt.

A recent analysis of the countries that report on an accrual basis, carried out by the Organisation for Economic Co-operation and Development (OECD) in 2017, highlights the situation about heritage asset accounting (see Table 1). This study reveals that the lack of a reference accounting treatment and the difficulties of establishing reliable and meaningful valuations result in only $43 \%$ of OECD governments reporting heritage assets.

Even when heritage assets are recognized on the balance sheet, different measurement methods can be applied, with each presenting different strengths and weaknesses. Historical cost, market value, value in use, contingent valuation, travel cost method, hedonic pricing method, expertise and symbolic/token value are the most common methods (Biondi, 2018). This has led to a variety of practices among countries and, as a consequence, limited the comparability (Mattei et al., 2020).

Two examples of countries that believe that heritage items could meet the criteria of asset recognition and have issued a specific accounting standard are the UK, with the Financial Reporting Standard (FRS) 30 (ASB, 2009) in 2009 (partially replaced by FRS 102 in 2015), and South Africa, with the Generally Recognized Accounting Practice (GRAP) 103 (NT, 2014) in 2008 (then amended in 2014). In particular, the British standard setter makes a distinction between non-operational and operational heritage assets. The first are those that are held and maintained by an entity principally for their contribution to knowledge and culture (FRS 30, p. 3 ), while the second are those that, in addition to being held for their heritage characteristics, are also used by the entity for other activities or to provide other services (e.g. an historic building used as an office accommodation). Another way to describe operational heritage assets is as heritage assets used for a non-heritage purpose. In this second case, they can be recorded as traditional tangible fixed assets (FRS 15). Concerning non-operational heritage assets, the accounting standard mainly focuses on the concept of "availability" of information on cost or value to report heritage assets in the balance sheet (FRS 30, par. 1), and provides details on the enhanced disclosure that such kind of assets deserve (FRS 30, par. 5-17). Recently, the FRS 30 has been partially superseded by FRS 102 (FRC, 2018), a single coherent financial reporting standard which is now the principal accounting standard in the UK financial reporting regime. However, as far as heritage assets are concerned (FRS 102, par. 34.49-34.56), no substantial change has occurred.

Similarly, the South African GRAP 103 states that, for heritage assets that have more than one purpose, the entity needs to assess whether the definition of heritage asset is met and only if an insignificant portion is held for use in the production or supply of goods or services or for administrative purposes. Otherwise, the entity should account for the asset following traditional tangible fixed assets accounting requirements (GRAP 103, par. 09). The GRAP 103 requires the recognition of heritage assets if the cost or fair value of the asset can be measured

\begin{tabular}{llll}
\hline & $\begin{array}{l}\text { Not recognized in the } \\
\text { balance sheet but } \\
\text { disclosure provided }\end{array}$ & Not reported at all & $\begin{array}{l}\text { Information not } \\
\text { available }\end{array}$ \\
\hline $\begin{array}{l}\text { Recognized in the balance sheet } \\
\text { Australia, Austria, Canada, the }\end{array}$ & $\begin{array}{l}\text { Israel, Korea, the } \\
\text { Czech Republic, Finland, }\end{array}$ & $\begin{array}{l}\text { Belgium, Chile, Denmark, } \\
\text { Greece, Hungary, Iceland, } \\
\text { France, New Zealand, Poland, }\end{array}$ & $\begin{array}{l}\text { Estonia, Japan, } \\
\text { the Slovak }\end{array}$ \\
$\begin{array}{l}\text { Slovenia, Spain, Sweden, the } \\
\text { UK }\end{array}$ & $\begin{array}{l}\text { Switzerland, Turkey } \\
\text { Republic }\end{array}$ &
\end{tabular}

Source(s): Adapted from OECD/IFAC (2017, p. 18)

\section{Heritage assets in financial reporting}


JPBAFM 33,5

\section{8}

"reliably" (GRAP 103, par. 13). If not, relevant and useful information about it shall be disclosed in the notes to the financial statements (GRAP 103, par. 17).

Since the issuing of IPSAS 17 in 2001, the IPSASB has acknowledged that heritage asset accounting should have been the subject of a further in-depth analysis later on. After a few years, a "Heritage" project was initiated to move toward the preparation of an international accounting standard for public sector entities, but this has faced many challenges (see Table 2).

After a long period of stalemate whilst waiting for the publication of the Conceptual Framework (CF) for general purpose financial reporting by public sector entities (IPSASB, 2014), the IPSASB issued the Consultation Paper (CP) entitled "Financial Reporting for Heritage in the Public Sector" in April 2017 (IPSASB, 2017a), seeking feedback to develop guidelines on the recognition, measurement and presentation for heritage.

Given its troublesome history and the above-mentioned unresolved issues, it is then reasonable to wonder if the heritage assets project will be a never-ending story, or whether it will finally have a happy ending. In different words, the research question that drives our investigation is: to what extent the $\mathrm{CP}$ is a step forward in the definition of an IPSAS for heritage assets accounting, when applied in an emblematic context, such as the Italian case?

\section{Italian cultural heritage: the state of the art}

The importance that cultural heritage has for Italy is reflected in the references included in its Constitutional Charter. Specifically, art. 9 requires the Republic to promote the development of culture as a tool for the growth and development of society (Sciullo, 2017), as well as to safeguard the environment and the historical and artistic heritage of the nation. Moreover, the reform of Title V and, later, the Code of Cultural Heritage and Landscape of 2004 (Landriani and Pozzoli, 2013), introduced an important distinction between the activity of safeguarding [1], which is within the remit of the central government, and the activity of appreciation [2], which is within the remit of the local government. This separation of activities is an essential element when it comes to identifying which reporting entity is responsible for a certain heritage asset, especially given that, in Italy, an overall system of governmental accounting drawn up according to the rules of accrual accounting does not yet exist. In reality, we are faced with a different discipline depending on whether the asset is included in the state financial reporting or instead owned by a local government or even a university.

First of all, in order to talk about assets of historical, artistic, and cultural interest, it is essential to analyse the definition currently used. Specifically, in Italy, cultural heritage is

\section{"Heritage" project}

2001 Issuing of IPSAS 17. Heritage assets will be the subject of further development

2004 A project brief on heritage asset accounting is activated. However, due to budget constraints, it is postponed

2005 Collaboration with the British Accounting Standards Board (ASB) for the joint development of a Consultation Paper on heritage assets

2006 Issuing of the Consultation Paper "Accounting for Heritage Assets Under the Accrual Basis of Accounting”, which embeds the ASB Discussion Paper "Heritage Assets: Can Accounting Do Better?"

2007 The project is halted due to other priorities

2010 Issuing of IPSAS 31 (Intangible assets)

2014 Issuing of the Conceptual Framework for General Purpose Financial Reporting by Public Sector Entities

2015 Approval of a new project brief on heritage assets

2017 Issuing of the Consultation Paper "Financial Reporting for Heritage in the Public Sector"

Source(s): Adapted from Biondi (2018, pp. 108-109)
Table 2.

The troublesome history of the "Heritage" project 
made up of cultural assets and landscape assets (Legislative Decree n. 42/2004, co. 1, art. 2). Cultural assets' definition includes fixed and noncurrent aspects that have the characteristics of attracting artistic, historical, archaeological, ethno-anthropological, archival and bibliographical interest, as well as other aspects identified by law or according to the law pertaining to evidence of civilization (co. 2, art. 2). Buildings and areas, however, that are an expression of the historical, cultural, natural, morphological, and aesthetic values of the territory, as well as other assets identified by law or according to the law (par. 3, art. 2), are considered landscape assets. From the analysis of the regulations, it can be deduced that cultural heritage is not considered as merely the sum of historical, artistic and archaeological assets, but rather as a set of expressions (whether tangible or not) regarding what is worthy of being transformed into heritage by a social group, with the aim of affirming and passing on its cultural identity over time (Piaia et al., 2020); in fact, the concept of cultural heritage is seen as the expression of a strategy to promote specific forms of identity and enhance, in a targeted way, the history of a people (Lupo, 2019). Therefore, a heritage item is recognised as a heritage asset if it is eternal and if it has characteristics that may lead it to become a testimony to an era and to be "inherited" by the community over the course of generations (Farneti et al., 2009).

The financial reports produced by the state, local government, or even universities do display some kinds of heritage assets, although not in a transparent manner, as we will discuss in more detail later. The need to define which public administration is responsible for the financial reporting of a specific asset should be recognised as one of the first critical factors to be identified in the Italian regulations, precisely because there is no overall system for governmental accounting.

A further criticality of the Italian regulations on the recognition of heritage assets is attributable to the accounting system traditionally used. As it is well known, until 2019, governmental accounting was based on the legal (or commitment) principle for which revenues and expenses were recorded when the obligation was fulfilled legally (Dabbicco and Mattei, 2020), without consideration, therefore, for the management of the assets. For just over ten years [3], that is since the introduction of L.196/2009, the Italian public sector has attempted to adopt accrual accounting, within the previous accounting system still used today.

Looking at the state's financial reporting, it is possible to find in the balance sheet the recognition of these types of assets in a document in which the consistency of the worth is shown. Within the "non-financial assets produced" it is possible to allocate the values relating to assets such as historical, artistic, archaeological, paleontological assets and restoration works (specifying whether they are noncurrent assets, which will be allocated under the item "noncurrent property of cultural value, libraries and archives", while all fixed property will be charged to the item "fixed property of cultural value"). However, the question of the evaluation of these assets remains. From the analysis of the Italian legislation, it emerges that the fixed assets to be indicated in the schemes are only those that are capable of generating income flows; therefore, all assets that are not subject to economic use are excluded from the accounting documents (Biondi, 2018). On the other hand, with reference to noncurrent assets, the discipline distinguishes the valuation according to the type of asset itself [4]. Another thorny issue relates to the update of the value because the rules set out in the Inter-Ministerial Decree of April 18, 2002 have usually either not been applied or been applied in a non-uniform way for different categories.

Shifting attention to the accounting documents drawn up by local authorities, which have also been subject to a profound reform of the accounting systems thanks to the issue of Legislative Decree no. 118/2011, despite being obliged to draw up a balance sheet, no specific category has been defined. The analysis of the chart of accounts, introduced by the Decree of the President of the Republic n.132/2013, reveals that there are items among the tangible fixed assets that draw attention to these assets [5]. The evaluation of these assets, according to the 
JPBAFM 33,5

540

accrual accounting principle (annex 4.3 of Legislative Decree 118/2011) must be made taking into account the purchase or production value, net of depreciation. For heritage assets obtained free of charge, an estimate is required.

As far as universities are concerned, it is important to note that they currently adopt an accrual accounting system, including a budget (that has an authorization function) and an annual statement (Biondi, 2013; Dabbicco and Mattei, 2020). Following the reforms, it was envisaged that universities should indicate in their accounting documents the "book heritage, works of art, antiques and museums". The operational technical manual, issued by the Ministry of University and Research, identifies how to estimate the value of book assets. Some books (such as publications instrumental to the institutional activity of teaching and research) are completely in line with the "eternal" definition and do not lose value over time, so that they are recognized in the balance sheet as assets. While other books (such as journals or scientific publications of temporary divulgation, used every day by the offices) are not considered eternal, lose value over time and - among the different possibilities for their accounting treatment - may be expensed in the income statement. So, we might say that the latter do not meet the definition of heritage assets.

From the above discussion, it can be seen that, in Italy, the discipline for the recognition and measurement of heritage assets is still new (Brusca and Montesinos, 2010) and the latest regulations are vague and ineffectively targeted. Therefore, it is possible to state that the (limited and inorganic) information reported in the financial statements of the national public sector can barely meet the information needs of stakeholders. This confirms, therefore, what has already been asserted by scholars in previous works, namely that Italy is probably not yet sufficiently autonomous and accountable to appreciate the full benefits of better information for internal and external purposes (Anessi-Pessina et al., 2010).

\section{Methodology}

In order to address the research question, we critically analyse the last document issued by the IPSASB concerning the "Heritage" project, namely the CP "Financial Reporting for Heritage in the Public Sector." A critical review is a qualitative research method that systematically assesses a work's effectiveness in order to highlight its strengths and weaknesses and to make recommendations (Paré et al., 2015; Paré and Kitsiou, 2017).

To this end, we adopt a document analysis as our primary investigation method, through the review of relevant documents (Corbetta, 2003) issued by the IPSASB and the MEF, that is $\mathrm{CP}, \mathrm{CF}$, preparatory documents from the IPSASB meetings, and the Italian comment letter (ICL). Therefore, we mainly rely on secondary data sources. For our purposes, these documents serve a twofold function: information contained therein suggests questions that need to be asked and situations that need to be observed; and preparatory documents provide a means of tracking change and development (Bowen, 2009). Consequently, a document analysis enables us to establish the meaning of the $\mathrm{CP}$ and its contribution to the issues being explored (Bowen, 2009).

In our analysis, we start from the assumption that, since many national and international regulators (e.g. ASB, FRAB, IPSASB) in recent years have sought the inclusion of heritage assets in financial statements, we cannot ignore that at least some of the heritage items can be regarded as assets (those that meet the accounting definition of an "asset" provided by the CF, as better specified henceforward) and that they need an accounting standard. As mentioned in the introduction, the Italian MEF (as one of the regulatory accounting bodies in Italy) also started a debate on heritage asset reporting by involving other institutions and academics (Aprile et al., 2018). Within this project, we as researchers actively took part in the drafting of the Italian comment letter (Biondi et al., 2018) so that we are well-informed people about the Italian point of view as well as the broad discussion underlying the Italian response. 
Therefore, as mentioned before, we mainly refer to the Italian context as we believe it is both a typical and a critical single case study. It is a typical case study in that it displays emblematic features of this phenomenon, given the high presence and huge variety of heritage assets. It is a critical case in that it entails logical generalization to other cases because what is true to this case is likely to be true to all other ones (and vice versa) (Patton, 1990; Yin, 2003). Hence, starting from Italy as an emblematic example entails us to expand our view then and make broader considerations that could apply to other contexts too.

Italian national heritage currently includes 55 United Nations Educational, Scientific and Cultural Organization (UNESCO) World Heritage sites (the highest number, along with China, but in a much smaller area) and 12 UNESCO Intangible Cultural Heritage items. Nevertheless, unlike in other jurisdictions (e.g. the UK and South Africa), as stated in Section 3, no specific national accounting standard for such items exists. One must analyse the specific regulation of the different Italian public sector entities to identify some isolated attempts to provide requirements for this particular category of items (e.g. cultural fixed assets of the central or local government and book holdings of universities) (Biondi, 2018). Hence, heritage assets are not the subject of consistent regulation in Italy.

\section{5. "Financial reporting for heritage in the public sector": towards a happy ending?}

The CP issued by the IPSASB adopts a systematic path, tackling the heritage asset accounting issues step by step. Following this approach, we will further discuss the following points: (1) definition of heritage item; (2) definition of heritage asset; (3) recognition; (4) measurement; (5) disclosure.

\section{(1) Definition of heritage item}

The starting point is the identification of heritage items and the necessity to develop their description (CP, pp. 13-15). Given the option between setting an exhaustive list and merely establishing identification criteria, the IPSASB chose the latter approach, suggesting the following definition, which highlights the specific characteristics of heritage assets:

Heritage items are items that are intended to be held indefinitely and preserved for the benefit of present and future generations because of their rarity and/or significance in relation, but not limited, to their archeological, architectural, agricultural, artistic, cultural, environmental, historical, natural, scientific or technological features. (CP, par. 2.11)

This definition results in line with the one provided by some Italian scholars which emphasise the concept of "eternity" and the feature of the asset to be inherited by the citizenry over the generations (Farneti et al., 2009).

In order to categorize the items meeting this definition, the IPSASB refers to the generally accepted definitions of the UNESCO World Heritage Convention (UNESCO, 1972). It separates cultural heritage from natural heritage; the first includes both tangible sites (e.g. monuments and historical buildings, archaeological sites, artworks, and natural and scientific collections) and intangible sites (so-called "knowledge-in-action" and intellectual property).

The second should contain, besides natural areas and features, living plants and organisms; however, since the latter have limited life, they do not fit the above-mentioned definition.

In Italy, the Cultural Heritage and Landscape Code (Legislative Decree 42/2004) contains a similar classification. However, it refers to "items" instead of "sites". This suggests that landscape heritage falls partly under the UNESCO's natural heritage category and partly under the UNESCO's tangible cultural heritage category (ICL, pp. 5, 7). For example, while the 
JPBAFM 33,5

542

historical city centre of Florence is considered a cultural site following the UNESCO's definition, by applying the Italian definition Piazza del Duomo is a landscape heritage item, while Galleria degli Uffizi is a cultural heritage item. Moreover, intangible cultural heritage is not considered at all in the Italian definition. For example, the art of the Neapolitan Pizza belongs to the UNESCO's intangible cultural heritage category, but it is not considered in the Italian jurisdiction (and, as we will see further on, neither considered "asset" by the IPSASB's $\mathrm{CP}$, being "knowledge-in-action").

(2) Definition of heritage asset

After defining heritage items, the $\mathrm{CP}$ goes on to discuss whether they fit the definition of an asset or not. To this end, one should refer to the IPSASB's CF, where an asset is defined as:

A resource presently controlled by the entity as a result of a past event (CF, par. 5.6)

Heritage items are resources. Indeed, they can provide services that contribute to achieving an entity's objectives (service potential). Further, it can be argued that they represent the entity's objective themselves (Paoloni and Grandis, 2007) through their contribution to knowledge and culture because, without them, the entity could not function (e.g. a gallery needs artworks to function as a gallery). In Italy, as explained in Section 3, preserving national heritage is even a constitutional principle. Moreover, even if this is not their primary goal, heritage items can also generate cash inflows (economic benefit), for example through admission charges, exploitation of reproduction rights or their use in the provision of services (CF, par. 5.7-5.10).

As far as the control requirement is concerned, this exists when an entity can: (1) demonstrate legal ownership, (2) allow access to the resource or limit the access, or (3) direct the use of the resource to achieve its objective (CP, par. 5.12). This is also the case for most heritage items held by entities. On this point, some scholars question that the societal benefits of a heritage item flow to the citizens and not to the government itself as an accounting entity (Christiaens et al., 2012, Task force IRSPM A\&A SIG, CIGAR Network, EGPA PSG XII comment letter). However, one can argue that the citizens are represented by the government and, conversely, the government is the political representation of the citizens; hence that distinction appears as not relevant.

What has previously determined the actual control of the resource may vary, for example purchase, donation or discovery. This is also the case for heritage items (CF, par. 5.13). Therefore, drawing on the $\mathrm{CF}$, the preliminary view of the IPSASB is that the distinctive characteristics of heritage items do not hinder them from being considered as assets (CP, par. 3.10). As far as "knowledge-in-action" is concerned, the IPSASB concludes that, even if they fall within the description of a heritage item, they cannot be controlled by a single entity and therefore cannot be considered as assets (CP, par. 3.8).

Those arguments about the future economic benefits or service potential provided, the control by the entity and the past event that determined it, are entirely in line with those claimed by the scholars who share the view that heritage items are assets (Hone, 1997; McGregor, 1999; Micallef and Peirson, 1997; Rowles, 1992). Those observations are applicable in the Italian context, too. In this regard, the Italian view explains that such assets are worthy of autonomous assessment since they are or were the subject of significant investments, they provide benefits in broad sense (economic, social, cultural, etc.), they are potentially transferable through normative acts (ICL, p. 7).

However, the Italian position partially dissents to the IPSASB's view that the intention to preserve heritage items for the benefit of present and future generations does not give rise to liabilities (ICL, p. 22), because it does not imply a present obligation or an outflow of resources that cannot be deferred (CP, par. 6.1-6.10). In fact, the Italian MEF asserts that heritage items 
are at the same time resources and obligations (ICL, p. 4). This position is partially in line with what Mautz $(1981,1988)$ advocated.

Given that heritage items can fulfil the definition of heritage assets, the accounting standards should then also address the following: (a) recognition; (b) measurement and (c) disclosure.

\section{(3) Recognition}

The recognition issue involves two criteria: the existence of an asset and the ability to measure it. Even if admitting that heritage items can be considered assets from an accounting perspective, as we have already discussed, many arguments in favour of and against recognition exist. Recognition entails measuring, which in turn involves the assignment of a monetary value to the asset. This implies the selection of an appropriate valuation method that should achieve some qualitative characteristics (relevance and representational faithfulness, understandability, timeliness, comparability, and verifiability) and take account of the constraints of information (materiality and cost-benefit analysis) (CF, par. 6.7). The measurement basis is considered appropriate when it provides information that enables users to assess: the cost of services provided, the operational capacity (i.e. the entity's ability to guarantee the delivery of services in the future), and the financial capacity (i.e. the entity's ability to have a stable financial position) (CF, par. 7.3). In the Italian view, even if recognition incurs some costs and the monetary value may understate the cultural value of heritage assets, the benefits of including heritage assets in an entity's financial statements are more significant for accountability and decision-making regarding the management of the asset, as well as giving useful information to users of GPFRs. This does not mean including misleading information in financial statements, but rather providing a prudent measure that addresses these qualitative characteristics for the purposes of accountability and decision-making. Moreover, disclosure could also contribute to achieving this goal by presenting descriptive information.

In fact, the objective of GPFRs is to provide financial information useful to users for making and evaluating decisions about the allocation of scarce resources, for assisting managers and governing bodies in discharging accountability and for assessing the performance of an entity (Rowles, 1992). Although the IPSASB acknowledges that it is unlikely GPFRs would provide all the information users need (CF, par. 2.31), as far as heritage assets are concerned, without any information at all about those category of assets that incompleteness would be huger. This means that, on the one hand, it is worth trying to recognize and measure those assets, and on the other hand, due to the problems that their recognition and measurement entail, additional disclosures as well as other sources of information may complement.

\section{(4) Measurement}

Regarding measurement criteria, the $\mathrm{CF}$ does not require a single method but provides guidance for the choice between historical cost, market value, replacement cost, net selling price and value in use (CF, par. 7.13-7.68). During the IPSASB meetings, the IPSASB Working Group of the Heritage project analysed these methods in order to assess their suitability for heritage asset reporting, reaching the IPSASB's preliminary view that only historical cost, market value and replacement cost are appropriate measurement criteria in valuing heritage assets.

Historical cost is the cost incurred upon the acquisition or development of the asset $(\mathrm{CF}$, par. 7.13-7.21). However, historical cost information may not be available or could be unreliable if the asset is ancient or has been obtained through non-exchange transactions. Market value is defined as "the amount for which an asset could be exchanged between knowledgeable, willing parties in an arm's length transaction” (CF, par. 7.24). Nevertheless, an open, active, and orderly market does not often exist for such goods, which are unique and in financial in financial reporting 
JPBAFM 33,5 incomparable. Replacement cost (CF, par. 7.37-7.48) requires an asset to be replaceable by another asset with the same service potential. Given that most heritage assets are irreplaceable, this method could be challenging to apply.

The Italian position, however, does not agree with the exclusion of the value-in-use measurement criterion, which could be one of the most appropriate approaches. According to the $\mathrm{CF}$, it is:

The present value to the entity of the asset's remaining service potential or ability to generate economic benefits if it continues to be used, and of the net amount that the entity will receive from its disposal at the end of its useful life. (CF, par. 7.58)

The Italian comment letter proposes a new concept of value in use based on the "usability" of the asset. In this way, this value could be a reasonable estimate by applying a discounted cash flow method for assets that provide future economic benefits, or the capitalization of the past expenditures that the entities have incurred to preserve and maintain the heritage asset to date for assets that do not provide (or provide limited) future economic benefits. In fact, the public resources, gathered through taxes paid by the citizenry, used to preserve and maintain the heritage through the controlling entity can also be used to estimate the social benefits attributed to the asset (ICL, pp. 12-18; Aprile et al., 2018).

The Italian view (ICL, p. 9) considers that the symbolic value of one currency unit (e.g. $1 €$ ), which was discussed and dismissed during the IPSASB meetings, should not be applied. On the contrary, some of the respondents to the consultation, seeing the pragmatism of this solution (IPSASB, 2019), believe that this method could instead be applied as an extrema ratio to give the heritage asset an initial measurement when other measurement criteria are not applicable, so that the subsequent expenditures will be capitalized on that initial amount.

This introduces the issue of the subsequent measurements, which also involve depreciation/amortization, impairment and revaluation (CP, par. 5.7-5.14). The IPSASB approaches this problematic point in broadly the same way as for the subsequent measurements of other non-heritage assets. Concerning depreciation, it is generally applicable to assets that have a finite useful life. However, this does not seem to be the case for most heritage assets, which, by definition, tend to increase their significance over time. For the same reasons, impairment does not seem, in principle, to be applicable. Just in case, IPSAS 21 "Impairment of non-cash generating asset" (IPSASB, 2008) can work as a reference. Regarding revaluation, the $\mathrm{CP}$ considers that the distinctive characteristics of heritage assets do not prevent this process from being applicable to them. The Italian view suggests that these assets could also undergo a process of periodic revaluation, as currently happens for non-heritage purpose assets. However, regarding this point, further in-depth studies on the subject are necessary (ICL, p. 20).

A possibility to explore in order to tackle those contentious matters is the distinction mentioned above between operational and non-operational heritage assets (already considered by FRS 30 and, in different words, by GRAP 102). This distinction could be helpful in ensuring the applicability of certain measurement bases. For example, one approach could be to value operational (i.e. non-heritage purpose) heritage assets in the same way as assets of that general type, that is initial cost less depreciation over their useful life (Aversano et al., 2020), while providing special measurement requirements and extraguidance only for the non-operational (i.e. heritage purpose) heritage assets, which conversely should not be depreciated.

(5) Disclosure

As far as disclosure is concerned, the $\mathrm{CP}$ concludes that the distinctive features of such assets do not require a particular presentation of information (CP, par. 7.1-7.9). The Italian position believes that information about such goods should be included in the statement of financial 
position and presented separately from other tangible fixed assets. However, we assert that enhanced disclosure in the notes to the account is needed to provide users with more comprehensive information about which heritage assets are reported and those which are not (and why), for the former what valuation method has been adopted for initial measurement and the reason underpinning the choice, how subsequent measurements have been conducted, as well as other important information that may assess the cultural value of the asset (ICL, p. 4). As Ellwood and Greenwood (2016, p. 11) conclude, "it is necessary to consider how both the economic and the cultural state of heritage assets can be reported".
Heritage assets in financial reporting

\section{Discussion}

Looking at the evidence emerged from the analysis, the main issues to point out are summarised below.

First, the boundaries of what items fall under the proposed definition of heritage items are quite blurred. Even if we agree with the principle-based approach, a clear identification of such goods could be challenging when considering the national jurisdiction criteria of different countries, as the Italian case demonstrates.

Second, regarding recognition, looking at the Italian case, we suggest that, although on the one hand a full-recognition approach is not applicable to all heritage items, on the other hand a non-recognition approach is not recommended for accountability and decisionmaking reasons. It follows that at least those heritage items that meet the "asset" definition provided by the $\mathrm{CF}$ should be recognized. Although acknowledging the difficulties of attaching an economic value to those assets, one has to bear in mind that any monetary value is a mere book value from a microeconomic perspective (the aim being the inclusion in the entity's financial report), which is not meant to embed the overall heritage significance for society. In our view, and considering the lessons learnt from the Italian case, the economic value is just a part of the overall cultural value, so trying to assign it a measure is in line with the prudence concept of accounting (Figure 1). This does not mean that the remainder of the cultural value can be ignored, rather that it can be represented in a different way, also disclosing qualitative information in the notes to the accounts, as better specified below.

Third, better guidance on the selection of the appropriate measurement criterion should be developed. The choice of the method should be led by the qualitative characteristics of the information and the applicability within the different national contexts. This should be done in an effort to minimize choice, thus increasing comparability. In our view, as the Italian case confirms, the value-in-use method should be reconsidered as one of the most suitable. To this

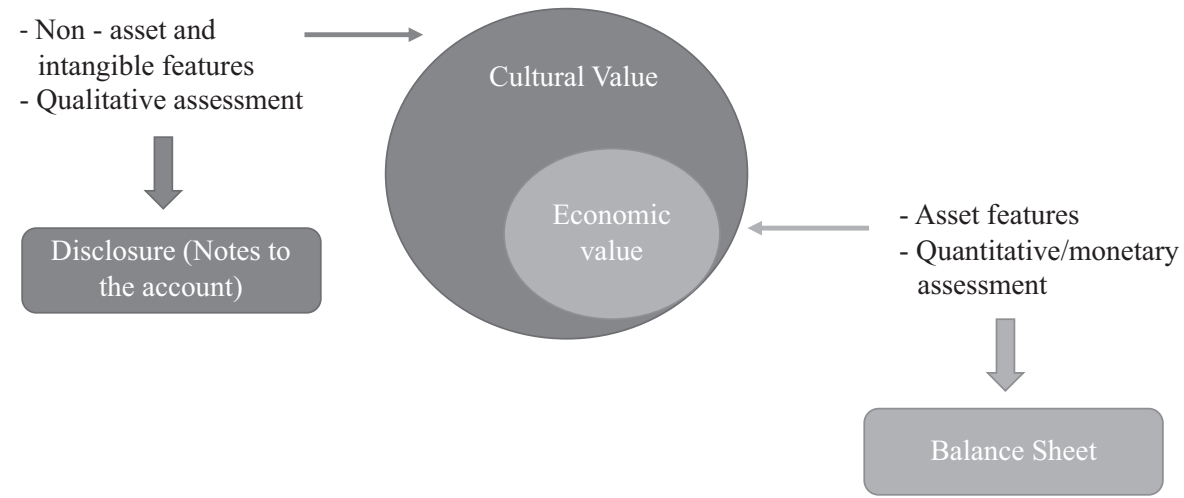

Figure 1. Economic and cultural value 
JPBAFM 33,5

\section{6}

end, in the light of the above considerations, the distinction between heritage purpose and non-heritage purposes assets could be useful.

Finally, in line with the Italian observations, we do not entirely agree with the IPSASB's view that heritage assets should be presented in line with existing IPSASB pronouncements. Enhanced disclosure is required in order to meet users' need for information. Information could be both qualitative and quantitative, financial and non-financial. Table 3 presents an example of what information could be displayed in the notes to the account. This would also allow auditors to analyse and compare data.

\section{Conclusions}

Following our analysis, we can try to answer our research question and present some preliminary conclusions. The CP issued by the IPSASB has undoubtedly drawn further attention to the unresolved issue of heritage asset accounting. The proposals therein represent a new step towards an organic regulation of heritage asset reporting. This could bring relevant changes and be particularly helpful to homogenize reporting in contexts such as the Italian one, where heritage assets are treated differently depending on the reporting entity.

Nevertheless, if those preliminary views are applied to the reality of an emblematic context, as the Italian case, it emerges that there remains much room for improvement related to different items, as: (1) the boundaries of the heritage assets; (2) the value recognition of these assets; (3) the adequate measurement criterion; (4) the content of the disclosure.

Taking Italy as a typical and critical case also allows us to expand our view to encompass broader considerations that could apply to other international contexts. From a theoretical point of view, this study's contributions lie in shedding light on the controversial issues that arise in developing an international accounting standard on heritage assets for the public sector, as well in trying to converge and harmonize the accounting and financial reporting among EU Member States, and among different public administration levels within a single country.

\begin{tabular}{|c|c|c|c|c|c|c|}
\hline Heritage item & $\begin{array}{l}\text { Heritage } \\
\text { asset }\end{array}$ & Amount & $\begin{array}{l}\text { Date of initial } \\
\text { and } \\
\text { subsequent } \\
\text { valuation }\end{array}$ & $\begin{array}{l}\text { Accounting policy } \\
\text { and measurement } \\
\text { criterion }\end{array}$ & Motivation & $\begin{array}{l}\text { Possible } \\
\text { alternative } \\
\text { methods }\end{array}$ \\
\hline $\begin{array}{l}\text { Name } \\
\text { Location } \text { Category }^{\mathrm{a}} \\
\text { Sub-category } \\
\text { Age } \\
\text { Entity } \\
\text { Other relevant } \\
\text { information }{ }^{\mathrm{d}}\end{array}$ & Yes/No & $\begin{array}{l}\text { Currency } \\
\text { unit }\end{array}$ & $-1-1-$ & $\begin{array}{l}\text { Historical cost/ } \\
\text { market value/ } \\
\text { replacement cost/ } \\
\text { value in use/ } \\
\text { symbolic value/ } \\
\text { other valuations }\end{array}$ & & \\
\hline \multicolumn{7}{|c|}{$\begin{array}{l}\text { Note(s): }{ }^{\text {a}} \text { Category }=\text { tangible, intangible, natural } \\
\text { bub-category = e.g. historical, archaeological, artistic, environmental etc. } \\
{ }^{\mathrm{c} E n t i t y}=\text { name, private or public } \\
{ }^{\mathrm{d}} \text { Other relevant information = e.g. entity's policies and budget for acquisition, preservation, management and } \\
\text { disposal; access permitted or not, number of visitors per year etc. } \\
{ }^{\mathrm{e}} \text { Other valuations = in this case, method used, if external valuer or not, name and professional qualification of } \\
\text { the valuer, limitations }\end{array}$} \\
\hline
\end{tabular}

Table 3.

Presentation of heritage-related information: a proposal the valuer, limitations 
The importance of defining, recognizing, measuring and disclosing heritage assets in financial reporting also has important practical implications. Recognizing heritage assets in the balance sheet would help to provide a more complete picture of the financial position of a government. Indeed, the protection, promotion and management of heritage assets, to preserve them for future generations, incurs expenditures, which consequently have a negative impact on the liability side. The recognition of such items on the asset side could improve the quality of financial statements that are intended to give a true and fair view of a reporting entity's financial position and income and expenditure.

Moreover, disclosing information on heritage assets could affect public managers and policy-makers, as well as other users of GPFRs (i.e. citizens) for the purposes of accountability, transparency and decision-making.

In light of the above discussions, it should also be noted that including heritage assets in an entity's financial report could lead to a better management of the asset and, consequently, an increase in the government revenues, as well as a reduction in government expenditures. This could positively affect the sustainability of the sovereign debt, with both enhanced primary surplus and increased gross domestic product, within the European fiscal policy rules. Moreover, even if considered as illiquid assets, national legislation by EU Member States could enforce the current Code of Conduct for Credit Rating Agencies issued by the International Organization of Securities Commissions (IOSCO, 2015) by including cultural heritage as a significant opportunity for social and economic development, which should be considered not only as an element to preserve but also as an element that has huge potential in sustaining and reinforcing the economic strength of a country, both in the short and long term. These implications are particularly true in those countries that have a huge cultural heritage and a high sovereign debt, such as Italy.

The main limitation of this study is that it does not currently provide any empirical evidence about the determination of specific heritage asset values. What we have discussed regarding measurement and the suggestion to find a different way to assess the value in use based on the concept of "usability" can be better developed in the future by proposing a new methodology to be tested for different kinds of heritage assets.

\section{Notes}

1. Safeguarding means all the activities and functions aimed at identifying the assets that make up the cultural heritage, and ensuring their protection and conservation so that they can be enjoyed by the public.

2. Appreciation means the combination of activities and functions aimed at promoting knowledge of the cultural heritage and ensuring the best conditions for the public use and enjoyment of the heritage to promote cultural development.

3. Previously, other attempts had been made regarding the introduction of accrual accounting, as in the case of the local healthcare authorities.

4. Some examples in this regard can be made by considering, for instance, book heritage. For these assets, it is important to take into account the date they entered the library. If this date is prior to 1875 , the assessment is made on the basis of bibliographic criteria and an update made considering certain criteria (including the trend of the antique market as opposed to the insured value, etc.), while if the book became part of the library after 1875 it has to be re-evaluated on the basis of ISTAT's (the Italian National Institute of Statistics) index and on a consideration of the library category. With reference, for example, to archival assets, it seems useful to point out that this type of asset is evaluated on the basis of the linear meters they occupy in the shelves.

5. For completeness, it should be noted that the items provided in the chart of accounts only consider tangible fixed assets, ignoring all cultural heritage assets that are intangible.

\section{Heritage assets in financial reporting}

\section{政}


JPBAFM 33,5

548

\section{References}

Accounting Standards Board (ASB) (2009), Financial Reporting Standard (FRS) 30 'Heritage Assets', FRC Publications, Kingston upon Thames.

Adam, B., Mussari, R. and Jones, R. (2011), "The diversity of accrual policies in local government financial reporting: an examination of infrastructure, art and heritage assets in Germany, Italy and the UK", Financial Accountability and Management, Vol. 27 No. 2, pp. 107-133.

Andriani, Y., Kober, R. and Ng, J. (2010), "Decision usefulness of cash and accrual information: public sector managers' perceptions”, Australian Accounting Review, Vol. 20 No. 2, pp. 144-153.

Anessi-Pessina, E., Nasi, G. and Steccolini, I. (2010), “Accounting innovations: a contingent view on Italian local governments", Journal of Public Budgeting, Accounting and Financial Management, Vol. 22 No. 2, pp. 250-271.

Anessi-Pessina, E., Caruana, J., Sicilia, M. and Steccolini, I. (2019), "Heritage: the priceless hostage of accrual accounting", International Journal of Public Sector Management, Vol. 33 Nos 2-3, pp. 285-306.

Anessi-Pessina, E. and Steccolini, I. (2007), "Effects of budgetary and accruals accounting coexistence: evidence from Italian local governments", Financial Accountability and Management, Vol. 23 No. 2, pp. 113-131.

Aprile, R., Grandis, F.G. and Mocavini, F. (2018), "Heritage come asset nella contabilitá economico-patrimoniale delle amministrazioni pubbliche", Rivista della Corte dei Conti, Nos 34, pp. 429-440.

Australian Accounting Standards Board (AASB) (2015), Australian Accounting Standards 116 Property, Plant and Equipment, Melbourne, AASBG.

Aversano, N., Christiaens, J., Tartaglia Polcini, P. and Sannino, G. (2020), “Accounting for heritage assets: an analysis of governmental organization comment letters on the IPSAS consultation paper”, International Journal of Public Sector Management, Vol. 33 Nos 2-3, pp. 307-322.

Barton, A.D. (2000), "Accounting for public heritage facilities - assets or liabilities of the government?", Accounting, Auditing and Accountability Journal, Vol. 13 No. 2, pp. 219-236.

Barton, A.D. (2005), "The conceptual arguments concerning accounting for public heritage assets: a note", Accounting, Auditing and Accountability Journal, Vol. 18 No. 3, pp. 434-440.

Barton, A.D. (2009), "The use and abuse of accounting in the public sector financial management reform program in Australia”, Abacus, Vol. 45 No. 2, pp. 221-248.

Biondi, L. (2013), L'università in cambiamento: Riflessioni in tema di contabilità e bilancio, Giappichelli Editore.

Biondi, L. (2018), La valutazione del patrimonio culturale nel bilancio delle Pubbliche Amministrazioni. Accounting for heritage assets, Wolters Kluwer - Cedam, Milano.

Biondi, L., Grandis, F.G. and Mattei, G. (2018), "Financial reporting for heritage assets. Towards an international public sector accounting standard?", Working papers n. 9/2018, Collana del Dipartimento di Economia Aziendale, Università Roma Tre.

Biondi, L. and Lapsley, I. (2014), "Accounting, transparency and governance: the heritage assets problem", Qualitative Research in Accounting and Management, Vol. 11 No. 2, pp. 146-164.

Bowen, G.A. (2009), "Document analysis as a qualitative research method", Qualitative Research Journal, Vol. 9 No. 2, pp. 27-40.

Brusca, I. and Montesinos, V. (2010), "Developments in financial information by local entities in Europe", Journal of Public Budgeting, Accounting and Financial Management, Vol. 22 No. 3, pp. 299-324.

Buscema, S. (1976), Patrimonio Pubblico, Giuffrè, Milano.

Carlin, T.M. (2005), "Debating the impact of accrual accounting and reporting in the public sector", Financial Accountability and Management, Vol. 21 No. 3, pp. 309-336. 
Carnegie, G.D. and Wolnizer, P.W. (1995), "The financial value of cultural, heritage and scientific collections: an accounting fiction”, Australian Accounting Review, Vol. 5 No. 9, pp. 31-47.

Carnegie, G.D. and Wolnizer, P. (1996), "Enabling accountability in museums", Accounting, Auditing and Accountability Journal, Vol. 9 No. 5, pp. 84-99.

Heritage assets in financial reporting

Carnegie, G.D. and Wolnizer, P.W. (1999), "Unravelling the rhetoric about the financial reporting of public collections as assets", Australian Accounting Review, Vol. 9 No. 1, pp. 16-21.

Carnegie, G.D. and Wolnizer, P.W. (2002), “A rejoinder”, Australian Accounting Review, Vol. 12 No. 3, pp. 45-47.

Cassandro, P.E. (1970), Le Gestioni Erogatrici Pubbliche, Utet, Torino.

Christensen, M. (2002), "Accrual accounting in the public sector: the case of the New South Wales government", Accounting History, Vol. 7 No. 2, pp. 93-124.

Christiaens, J. and Rommel, J. (2008), "Accrual accounting reforms: only for businesslike (parts of) governments", Financial Accountability and Management, Vol. 24 No. 1, pp. 59-75.

Christiaens, J., Rommel, J., Barton, A. and Everaert, P. (2012), "Should all capital goods of governments be recognized as assets in financial accounting?", Baltic Journal of Management, Vol. 7 No. 4, pp. 429-443.

Corbetta, P. (2003), Social Research: Theory, Methods and Techniques, Sage, London.

Dabbicco, G. and Mattei, G. (2020), "The reconciliation of budgeting with financial reporting. A comparative study of Italy and the UK", Public Money and Management, Vol. 41 No. 2, pp. 127-137.

De Wolf, A., Christiaens, J. and Aversano, N. (2020), "Heritage assets in the due process of the international public sector accounting standards board (IPSASB)", Public Money and Management, pp. 1-11, doi: 10.1080/09540962.2020.1727114.

Ellwood, S. and Greenwood, M. (2016), “Accounting for heritage assets: does measuring economic value 'kill the cat'?", Critical Perspectives on Accounting, Vol. 38, pp. 1-13.

EU Commission (2013), "Report from the commission to the council and the European parliament towards implementing harmonised public sector accounting standards in member states: the suitability of IPSAS for the member states", available at: https://eur-lex.europa.eu/legal-content/ EN/TXT/?uri $=$ celex $\% 3 A 52013 D C 0114$.

Evans, M. (1995), Resource Accounting and Budgeting in Government: The Policy Framework, Chartered Institute of Public Finance and Accountancy, London.

Farneti, G., del Sordo, C. and Levy Orelli, R. (2009), "Heritage assets in Italian local governments", Conservation Science in Cultural Heritage, Vol. 9 No. 1, pp. 17-33.

Financial Accounting Standards Board (FASB) (2008), Conceptual Framework for Financial Reporting, Financial Accounting Standards Board, Norwalk, CT.

Financial Reporting Council (FRC) (2018), Financial Reporting Standard (FRS) 102 'The Financial Reporting Standard Applicable in the UK and Republic of Ireland', The Financial Reporting Council, London.

Guthrie, J. (1998), "Application of accrual accounting in the Australian public sector-rhetoric or reality", Financial Accountability and Management, Vol. 14 No. 1, pp. 1-19.

Hone, P. (1997), "The financial value of cultural, heritage and scientific collections: a public management necessity”, Australian Accounting Review, Vol. 7 No. 1, pp. 38-43.

Hood, C. (1991), “A public management for all seasons?”, Public Administration, Vol. 69 No. 1, pp. 3-19.

Hood, C. (1995), "The 'new public management' in the 1980s: variations on a theme", Accounting, Organizations and Society, Vol. 20 Nos 2-3, pp. 93-109.

International Accounting Standards Board (IASB) (2018), Conceptual Framework for Financial Reporting, IFRS Foundation, London.

International Organization of Securities Commissions (IOSCO) (2015), Code of Conduct Fundamentals for Credit Rating Agencies, International Organization of Securities Commissions, Madrid. 
JPBAFM 33,5

International Public Sector Accounting Standards Board (IPSASB) (2000), IPSAS 17: Property, Plant and Equipment, New York, NY, IFAC.

International Public Sector Accounting Standards Board (IPSASB) (2008), IPSAS 21: Impairment of Non-cash-generating Assets, IFAC, New York, NY.

International Public Sector Accounting Standards Board (IPSASB) (2010), IPSAS 31: Intangible Assets, IFAC, New York, NY.

International Public Sector Accounting Standards Board (IPSASB) (2014), Conceptual Framework for General Purpose Financial Reporting by Public Sector Entities, IFAC, New York, NY.

International Public Sector Accounting Standards Board (IPSASB) (2017a), Consultation Paper "Financial Reporting for Heritage in the Public Sector", IFAC, New York, NY.

International Public Sector Accounting Standards Board (IPSASB) (2017b), “Agenda item 7: heritage", IPSASB Meeting, 5-8 December 2017, Toronto, Canada, available at: https:/www.ipsasb.org/ system/files/meetings/files/Agenda-Item-7-Heritage.pdf.

International Public Sector Accounting Standards Board (IPSASB) (2019), "Agenda item 7: heritage", IPSASB Meeting, 12-15 March 2019, Washington, DC, available at: https://www.ifac.org/ system/files/meetings/files/7-Heritage-Final.pdf.

Jaenicke, H.R. and Glazer, A.S. (1991), Accounting for Contributions and Collection Items, American Association of Museums, Washington, DC.

Jaenicke, H.R. and Glazer, A.S. (1992), "Art and historical treasures: a solution to the museum collection controversy", The CPA Journal, Vol. 62 No. 3, p. 46.

Landriani, L. and Pozzoli, M. (2013), Management and Valuation of Heritage Assets: A Comparative Analysis between Italy and USA, Springer Science \& Business Media, Berlin.

Lapsley, I., Mussari, R. and Paulsson, G. (2009), "On the adoption of accrual accounting in the public sector: a self-evident and problematic reform”, European Accounting Review, Vol. 18 No. 4, pp. 719-723.

Lupo, A. (2019), "La nozione positiva di patrimonio culturale alla prova del diritto globale", Aedon, Vol. 2, pp. 1-13.

Manes Rossi, F., Cohen, S., Caperchione, E. and Brusca, I. (2016), "Harmonizing public sector accounting in Europe: thinking out of the box", Public Money and Management, Vol. 36 No. 3, pp. 189-196.

Mattei, G., Jorge, S. and Grandis, F.G. (2020), "Comparability in IPSASs: lessons to be learned for the European standard", Accounting in Europe, Vol. 17 No. 2, pp. 158-182.

Mautz, R.K. (1981), "Financial reporting: should government emulate business?", Journal of Accountancy, Vol. 2, pp. 53-60.

Mautz, R.K. (1988), "Monuments, mistakes and opportunities”, Accounting Horizons, Vol. 2 No. 2, pp. 123-128.

McGregor, W. (1999), "The pivotal role of accounting concepts in the development of public sector accounting standards", Australian Accounting Review, Vol. 9 No. 1, pp. 3-8.

Micallef, F. and Peirson, G. (1997), "Financial reporting of cultural, heritage and scientific collections", Australian Accounting Review, Vol. 7 No. 13, pp. 31-37.

National Treasury (NT) of South Africa (2014), Generally Recognised Accounting Practice (GRAP) 103 'Heritage Assets', National Treasury, South African Government, Pretoria.

Nasi, S., Hansen, K. and Hefzi, H. (2001), "Off balance sheet assets in central governments. Are they unique or are they really assets?", Journal of Interdisciplinary Studies, Vol. 14 No. 2, pp. 137-154.

New Zealand Accounting Standards Board (NZASB) (2014), Public Benefit Entity International Public Sector Accounting Standard 17 Property, Plant and Equipment (PBE IPSAS 17), New Zealand Accounting Standards Board, Wellington.

Organisation for Economic Co-operation and Development/International Federation of Accountants (OECD/IFAC) (2017), Accrual Practices and Reform Experiences in OECD Countries, OECD Publishing, Paris. 
Pallot, J. (1990), "The nature of public sector assets: a reply to Mautz", Accounting Horizons, Vol. 4 No. 2 , pp. $79-85$.

Paoloni, M. and Grandis, F.G. (2007), La Dimensione Aziendale Delle Amministrazioni Pubbliche, Giappichelli, Torino.

Paré, G. and Kitsiou, S. (2017), "Methods for literature reviews", in Lau, F. and Kuziemsky, C. (Eds), Handbook of eHealth Evaluation: An Evidence-Based Approach, University of Victoria, Victoria.

Paré, G., Trudel, M.C., Jaana, M. and Kitsiou, S. (2015), "Synthesizing information systems knowledge: a typology of literature reviews", Information and Management, Vol. 52 No. 2, pp. 183-199.

Patton, M.Q. (1990), Qualitative Evaluation and Research Methods, Sage, Newbury Park, CA.

Paulsson, G. (2006), "Accrual accounting in the public sector: experiences from the central government in Sweden”, Financial Accountability and Management, Vol. 22 No. 1, pp. 47-62.

Piaia, E., Maietti, F., Di Giulio, R., Schippers-Trifan, O., Van Delft, A., Bruinenberg, S. and Olivadese, R. (2020), "BIM-based cultural heritage asset management tool. Innovative solution to orient the preservation and valorization of historic buildings", International Journal of Architectural Heritage, pp. 1-24, doi: 10.1080/15583058.2020.1734686.

Rowles, T.R. (1992), "Financial reporting of infrastructure and heritage assets by public sector entities", AARF Discussion Paper n. 17, Australian Accounting Research Foundation, Caulfield.

Schuler, C., Fuchs, S. and Bergmann, A. (2015), "The role of heritage assets in public financial reporting: an assessment on the current status of financial reporting of heritage assets in Switzerland", Yearbook of Swiss Administrative Science, Vol. 6 No. 1, pp. 197-211.

Sciullo, G. (2017), "Corte costituzionale e nuovi scenari per la disciplina del patrimonio culturale", Aedon, Vol. 1, pp. 1-6.

Stanton, P.J. and Stanton, P.A. (1997), "Government accounting for heritage assets: economic, social implications", International Journal of Social Economics, Vol. 24 Nos 8-9, pp. 988-1006.

Treasury Accounting Policy Team (2002), Valuation Guidance for Cultural and Heritage Assets, Treasury Accounting Policy Team, Wellington, available at: https://www.treasury.govt.nz/ sites/default/files/2007-09/val-guide-cultural.pdf.

United Nations Educational, Scientific and Cultural Organisation (UNESCO) (1972), Convention Concerning the Protection of the World Cultural and Natural Heritage: Adopted by the General Conference at its Seventeenth Session Paris, 16 November 1972, UNESCO, Paris, available at: https://whc.unesco.org/archive/convention-en.pdf.

Woon, P.P., Chatterjee, B. and Cordery, C.J. (2019), "Heritage reporting by the Australian public sector", Accounting, Auditing and Accountability Journal, Vol. 32 No. 2, pp. 612-631.

Wynne, A. (2007), "Is the move to accrual based accounting a real priority for public sector accounting?", Public Fund Digest, Vol. 6 No. 1, pp. 25-38.

Yin, R.K. (2003), Case Study Research: Design and Methods, Sage, Thousand Oaks, CA.

\section{Further reading}

Accounting Standards Board (ASB) (1999), Financial Reporting Standard (FRS) 15 'Tangible Fixed Assets', FRC Publications, Kingston upon Thames.

\section{Corresponding author}

Lucia Biondi can be contacted at: lucia.biondi@uniroma3.it

For instructions on how to order reprints of this article, please visit our website:

www.emeraldgrouppublishing.com/licensing/reprints.htm

Or contact us for further details: permissions@emeraldinsight.com

Heritage assets in financial reporting 